\title{
Improving Fluency Skill in English Speaking Through Role Playing Learning Strategy at English Study Program, Administration Business Department, State Polytechnic of Madiun
}

\author{
Imam Mudofir; M. Farid Maftuh ${ }^{1}$; M. Supriyanto ${ }^{2}$; Henny Purwaningsih ${ }^{3}$ \\ ${ }^{1}$ Lecturer in English Study Program at State Polytechnic of Madiun, East Java, Indonesia \\ ${ }^{2}$ Lecturer in Business Administration Study Program at State Polytechnic of Madiun, East Java, Indonesia \\ ${ }^{3}$ Lecturer in Civil Engineering Study Program at State Polytechnic of Malang, East Java, Indonesia
}

http://dx.doi.org/10.18415/ijmmu.v6i4.934

\begin{abstract}
In the preliminary study, the researchers found that the average value of fluency in English speaking is 2.25. This is because of the teacher always uses monotonous, less enjoyable learning strategy and the teacher only focuses on completing the material so that the learning process can only transfer knowledge so that the level of mastery of the material is low which ultimately decreases student achievement. To overcome this problem, researchers propose a strategy in teaching speaking skill, namely role-playing learning strategy. This study is designed to improve fluency in English speaking by using role playing learning strategy. This study aims to explain how role-playing learning strategy can improve fluency in English speaking in the 4th semester, English Study Program, Business Administration Department, State Polytechnic of Madiun. This study uses a Classroom Action Research (CAR) design which is collaborative in nature where researchers and teacher collaborate in carrying out this research. Researcher act as observer while English teacher become collaborator of researcher in implementing role playing learning strategy. This research was carried out in a cycle that refers to procedures for action research, namely planning, implementing, observing, and reflecting. Each cycle in this study consisted of two meetings. The research data was collected through several instruments, namely evaluation of English speaking, questionnaires, and field notes. The subjects of this study were 4th semester of D3 Program students, English Study Program, Business Administration Department, State Polytechnic of Madiun. The results of the overall average score of fluency in English speaking in the first cycle of 2.44, in the second cycle of 2.89, and in the third cycle of 3.19. Classroom action research can be stopped in cycle III because it is in accordance with the average criteria of success is 3.01. The interesting of students towards the implementation of role-playing learning strategy shows that students are happy and interested in implementing role playing learning strategy.
\end{abstract}

Keywords: Improvement of Speaking Skills; Role Playing Learning Strategy; Classroom Action Research (CAR) 


\section{Introduction}

English speaking is still considered a difficult ability for students especially in fluency. Role playing learning strategy is also expected that students are happy and have the spirit of learning in a classroom atmosphere that is free to express their opinions in accordance with their respective roles. This is consistent with the results of the research of Adnyani (2014), Argaruri (2014), As'adi (2011), Heliyanti (2014), Purwanto (2013), Rianti (2013), Susilo (2011), Sutino (2011), Triyanto ( 2013), Widiastuti (2012), and Khudriyah (2010) which states that role playing learning strategy can improve student learning outcomes. The researchers found fluency skills in English speaking in the fourth semester in public speaking courses were still low, which was an average of 2.25. This condition can affect students' speaking ability in the process of learning English and will also affect students in facing public speaking courses in the fourth semester. Based on the problems above, the researcher intends to make improvements in improving fluency in English speaking in public speaking courses through Classroom Action Research (CAR) which is an activity testing an idea in practicing or a real situation in the hope that the activity is able to improve the quality of the teaching and learning process. Based on the results of observations and reflections on the learning that has been carried out, the problem in this study is "How can role playing learning strategy improve fluency skills in English speaking for the students of State Polytechnic of Madiun?" The purpose of this study is to improve fluency skills in English speaking for the students of State Polytechnic of Madiun.

\section{Literature Review}

Martinis Yamin (2008) states that the role playing strategy is a learning strategy that involves interaction between two or more students about a topic or situation. Students perform their respective roles according to the character they act. They interact and perform open roles. Students are given the widest opportunity to play so that they find problems that will be faced in actual implementation. According to Oemar Hamalik (2005) role playing is a simulation method that is generally used for social education and inter-human relations. Students participate as players with certain roles or as observers depending on the objectives of implementing the learning strategy. Treflinger (in Herman J. Waluyo, 2002) reveals that deciding upon the historical scenes of the past, possible events of the future, significant current events, or imaginary situations at any place or time. It can be interpreted that role playing is acting out of a regular regulatory decision, for purposes such as re-creating historical scenes from past events, allowing future events, or significant real events. Lee (1986: 147) explains that role playing learning strategy is useful to help bring language into life or provide real experiences to learners by using language as a communication tool. Amato (2003) also adds that through the role playing learning strategy activities learners can explore their abilities. According to Harmer (2007) role playing can be useful to spur oral fluency and train learner abilities in specific skills, especially in learning English. Brown (2001) divides speaking skills into taxonomies that arise in oral production. This taxonomy is from imitative to extensive, namely: imitative, intensive, responsive, interactive and extensive (monologue). As the statement of Brown above, the role playing learning strategy is one of the most spoken oral production activities. In the role playing learning strategy there are activities that can invite students to interact with each other.

Activities in Richards and Renandya's (2002) speaking skills were divided into four categories: 1) aural: oral activities, 2) visual: oral activities, 3) material-aided: oral activities and 4) culture awareness: oral activities. Role playing learning strategy activities carried out in the classroom with the role of teacher and students contain the two categories mentioned above, namely aural: oral activities and cultural awareness: oral activities. Meanwhile, Harmer (2007) suggests various activities that support the improvement of speaking skills in the learning process, namely: 1) Acting from a script, 2) Communication games, 3) Discussion, 4) Prepared talks, 5) Questionnaires, 6) Simulation and role 
playing. While Bailey in (Nunan, 2003: 56) designed several activities that can be applied in speaking classes, namely: 1) information gap, 2) jigsaw activities, 3) role-plays, 4) simulations, and 5) contact assignments. Lee (1986) adds that role-playing is an aspect of simulation. It can be concluded that role playing is part of a simulation activity, where the learners play a role in the overall situation. Speaking is designed to produce some effects on the environment between and listeners and readers (Brown in Tarigan, 1981). Speaking there is a series of actions or actions that contain the intent and purpose. The main purpose of speaking is to communicate so that you can express your thoughts effectively. Harmer (2007) suggested that "a good plan requires coherent variations that are coherent".

This statement expects the teacher to provide varied learning activities that are related to one another where students learn the same topic but students are stimulated with varied activities so that students do not feel bored or bored. Brown and Yule (Nunan, 1989) argue that speaking is using spoken language consisting of short, intact or fragmented speeches within the scope of pronunciation. The pronunciation is very closely related to the reciprocal relationships that are carried out between the speaker and the listener. Bailey (Nunan, 1989) states that speaking is an oral skill consisting of producing systematic language expressions to convey meaning. Students must be involved in a variety of oral activities, as well as providing opportunities for students to practice speaking, so the teacher is able to create scenarios that can motivate students to practice speaking English. Nunan, (1989) concluded from a number of theories and research that "study speaking in a second language or a foreign language will be facilitated when students actively participate in communication." From the explanation above the teacher must have good planning before doing classroom learning. Good planning must be based on 4 aspects proposed by Harmer (2007) in addition to planning good material preparation, the teacher must consider learning strategies that are good and suitable with the material to be taught. The teaching and learning process known as contextual learning (contexual teaching and learning) states that learning will be meaningful when the teacher is able to harmonize the material being studied with the context of real life and students according to what they are learning. According to Hadfield and Hammer (2007), the teaching procedure for speaking skills has 3 (three) levels, generally are: initial activities (setting up, engaging) speaking speaking practice, feedback (feed back) and introducing EAS stands for engage activities, core activities (speaking), learning (study), both are only different in terms. Richards \& Renandya (2002) argued that there are several components that underlie the success of 3 teaching speaking. These components are grammatical competencies, discourse competencies, sociolinguistic competencies, strategy competencies. Grammatical competencies are grammatical competencies (morphology and syntax), and vocabulary, including English sounds and spelling, pronunciation, intonation, stressing, etc.

Discourse competence (discourse) relates to the types of text used in context or applied with full functional significance. Sociolinguistic competency refers to knowledge of what is expected by target language users socially and culturally, including how the language is used in accordance with the situation of the existing sociol culture of the local community. What is meant by strategy competence is the way to use language to achieve the goal of communicating appropriately, well, and correctly. Based on the explanation above, role playing activities are very suitable for improving the speaking ability of students of State Polytechnic of Madiun. Speech fluency has been defined as "automaticity and speed of production of speech" (Brand \& Götz, 2011, p. 256). However, the automaticity and speed of speech production do not always make speech understandable. Understanding of speech can be understood as a measure of ease or difficulty perceived by listeners in understanding speech by using a second language. Crowther et al. (2015) only mentions "segmental, word pressure, rhythm, and speech level" as an example of fluency. Brand and Götz (2011) only use temporal variables from fluency such as "speech level, length of speech or number and length of pauses filled and not filled". Speech fluency is determined by several components such as speech speed or number of pauses filled and unfilled, number of errors, and use of formula language (Bøhn, 2015; Gut, 2009; Housen \& Kuiken, 2009). A broader definition of fluency, 
therefore, is needed in exploration studies. That is, fluency in speaking must be broadly defined as the ability of students to produce a quick and comprehensive speech (Brand \& Götz, 2011; Crowther et al., 2015). In broad definition, search for words cannot be observed. In addition, grammar allows students to get information without ambiguity, and aspects of speech performance - such as er, erm, and ah - are used to maintain the flow of discourse (Brand \& Götz, 2011; Nakatani, 2010). Speaking is a difficult skill, because special skills are needed in producing it. Specific skills are the choice of words, the use of structure, pronunciation, and knowledge of the sound system. The choice of words means that we must have a lot of vocabulary that we know to use. So that the speaker can tell the listener clearly and correctly. But vocabulary is a problem for students (Schultz, 1976). In addition, language usage habits and body cues are needed to produce language.

The speaking aspects include 1) vocal communication which includes interesting voices, voices that help focus on concepts, sounds that pay attention to the messages delivered, pleasant voices, voices that can explain well, and clear voices, 2) pronunciation and diction includes accents and pronunciation, 3) fluency and clarity which includes the ability to produce words, selection of words, clarity of understanding between speakers and listeners, 4) communication of the body which includes the appearance of eye and face movements, cues, concealment, group or organizational affiliation, status, role, and expression, 5) determine the purpose of speaking, 6) analyze the audience and situation, 7) select and simplify the discussion, 8) collect material, 9) make the outline speak, 10) string good words in speech, 11) delivering explanations by speaking. (Arevat \& Nation, 1991; Devito, 1990; Fletcher, 1990). Based on the speaking aspect, it can be concluded that the speaking component is response, coherence, vocabulary, grammar, pronunciation, fluency, and clarity (Mudofir, 2014). The ability to speak languages is one product of language learning and speaking is also an important part of the language learning process. Klippel (1984) states that "English speaking is a real communicative situation in which they learn to express their own views and attitudes". Speaking is a tool for expressing feelings, opinions, and attitudes verbally which is a real communication.

\section{Research Methods}

This type of research is quantitative and qualitative by using Classroom Action Research (CAR) with the type of participant action research by taking the research subjects as purposive random sampling. Quantitative is related to numbers derived from fluency test scores speaking English. Qualitatively related to the questionnaire that about student interest in following the learning process by using role playing learning strategies to improve fluency skills speak English. The method used in planning research follows the Mc model. Niff (1988) which consists of four steps up to a certain cycle that is considered successful according to the criteria of success. The stages of each cycle are: preliminary observation is 2.25 , planning, implementing, observing, reflecting, and triangulation.

\section{Research Results and Discussion}

\section{Cycle I}

\section{Planning}

Before carrying out actions and observations in the first cycle, a plan of action is established in advance, which is to plan the implementation of learning. The results of the planning implementation of learning are discussed together with collaborators. The design of learning materials designed by researchers and collaborators is as follows: 1 ) the role of chairman of committee. 


\section{Implementation of Actions and Observations}

The research step after designing the action is to carry out the action and observe or observe each behavior of the research subject while doing role playing activities. Role playing activities are carried out in the form of groups in which there are four-five students. Meanwhile, the steps of learning activities are divided into three activities, namely pre-activity, whilst-activity, and post-activity. Preactivity is a preliminary activity. Whilst activity is a core activity. This activity is a role-playing activity at a time when students are playing the role of chairman of committee. The last activity is post-activity.

\section{a. Meeting 1}

The first meeting was about the activity of explaining the material about public speaking (speech of chairman of committee) and role-playing training. This material is divided into three major parts, namely the beginning of the lesson, during the lesson, and the end of the lesson. At the pre-activity the lecturer gives an opening greeting, lectures students, motivates students, shares material and worksheets, and divides students into several groups. In the whilst activity, the lecturer gives material about public speaking (speech of chairman of committee). Students are also trained in pronunciation by imitating expressions, or English expressions used during teaching practice, including greetings, background (history and purpose of the program), achievements of the programs, and closing. Students are trained in role playing learning strategies in their respective groups. In post-activity, the lecturer tells students to prepare activities at the next meeting and close the learning process.

\section{b. Meetings 2 and 3}

Meetings 2 and 3 contain role-playing implementation activities. Meetings 2 and 3 are the same activities because lecturers hold an assessment one by one of students who need a long time for students who act as chairman of committee. In the pre-activity activity, students prepare themselves in their respective groups. On whilst-activity, students present their speaking skills through role-playing activities. In the first session, assessing the appearance of students in the fluency aspect of English speaking. In post-activity, collaborators give appreciation and correction to role-playing performances.

\section{Reflection}

The researcher conducted a reflection to find out whether the implementation of role-playing learning strategy in the first cycle had a positive effect to improve English speaking skills. Reflections are two aspects, namely reflection on students' enjoyment and interest in implementing role-playing learning strategy in improving students' English speaking skills, field notes during the learning process, and improving students' English speaking skills. In the first cycle shows that students are not active enough to speak using English in the learning process in the classroom. At the first meeting, there were only a few students who dared to ask researchers regarding English material as the language of instruction in the learning process. In meeting 2 and 3 in this first cycle, less active students use the opportunity to speak English. They do not interact with each other using English but interact with body language such as nodding, smiling, laughing, shaking their heads, or frowning. The interaction between students in role playing activities was unsuccessful. The following are some conclusions about matters related to improving English speaking skills of students in cycle I. First, the activeness of speaking in this cycle I role-playing activity has not been successful. It can be seen that some students have not been able to use English well in explaining material, especially in the implementation of role-playing meetings 2 and 3. They are not ready and are afraid of making mistakes in role-playing. Second, lecturer and student interaction is quite good. In general, the chairman of committee has been able to deliver subject matter according to the stages even though there are some students not systematically in delivering lessons, 
especially at meeting 1 because they forget and are nervous. Third, this interaction between students in cycle 1 role-playing activities was unsuccessful. Students do not make good use of role-playing strategies in which students who play the role of chairman of committee cannot maximize their roles. Fourth, the attention in this cycle I role-playing activity is quite successful. In this cycle 1 role-playing activity, all students pay attention to the lecturer's explanation well.

\section{Table 1. Value of Fluency Skills in English Speaking in Cycle I}

\begin{tabular}{|c|c|c|c|}
\hline \multirow{2}{*}{ No. } & Score & \multirow{2}{*}{ No. } & Score \\
\cline { 2 - 4 } \cline { 4 - 4 } & Fluency & & Fluency \\
\hline 1. & 1 & 15. & 2 \\
\hline 2. & 2 & 16. & 3 \\
\hline 3. & 2 & 17. & 3 \\
\hline 4. & 2 & 18. & 3 \\
\hline 5. & 2 & 19. & 3 \\
\hline 6. & 2 & 20. & 3 \\
\hline 7. & 2 & 21. & 3 \\
\hline 8. & 1 & 22. & 3 \\
\hline 9. & 3 & 23. & 3 \\
\hline 10. & 2 & 24. & 3 \\
\hline 11. & 2 & 25. & 3 \\
\hline 12. & 1 & 26. & 4 \\
\hline 13. & 2 & 27. & 3 \\
\hline 14. & 3 & & \\
\hline Total & \multicolumn{3}{|c|}{$\mathbf{6 6}$} \\
\hline Average & \multicolumn{2}{|l}{$\mathbf{2 4}$} \\
\hline
\end{tabular}

The value of English speaking skills on the fluency aspect which starts from the ability to open, convey, and close lessons by using English can be seen in table 4.1. The following is a summary of the average value of speaking English in the first cycle:

Based on the results of the achievement of speaking skills in the first cycle visualized through the table above is the total fluency value of speaking English students a total value of 66 and a fluency average value of $2 \mathrm{~A}$ semester $4 \mathrm{~A}$ of 2.44

\section{Cycle II}

\section{Planning}

The formulation of the plan in the second cycle is the strengthening of the implementation of the role-playing method to improve English speaking skills, namely sharpening reflection, especially on some problems whose achievements are still lacking. These problems are active speech, lecturer and 
student interaction, interaction between students, and student attention in the English learning process, and fluency skills speak English students.

\section{Implementation of Actions and Observations}

In an effort to solve the problems faced by students in the implementation of the second cycle of action carried out three times. Meeting 1 is giving material about public speaking. Meetings 2 and 3 are role-playing activities in which the implementation process is observed and assessed.

\section{(a) Meeting 1}

The 1st meeting in cycle II was carried out by discussing about public speaking and the roleplaying learning strategy training to improve fluency skills in speaking English. Discussion is stated as necessary because based on observation; students often make mistakes in pronouncing a word and even a sentence. In the pre-activity, the activity is in the form of class preparation and is followed by the whilstactivity activity which is an explanation of the material of public speaking on the speech of chairman of committee and practice by using role playing learning strategy. To facilitate understanding, examples of vocabulary related to the speech of chairman of committee are prepared. In post-activity, the activity ends with a conclusion about public speaking on the speech of the chairman of committee in the practice of the next role-playing.

\section{(b) Meetings 2 and 3}

Meetings 2 and 3 of the second cycle are the implementation of role-playing learning strategy in improving fluency skills speaking English students. In pre-activity activities in the form of preparation of the practice of role-playing by students. In whilst-activity, role-playing activities carried out by students vary which focus is on the observations made by the researcher, namely observations on the fluency aspect.

\section{Reflection}

Cycle II shows an increase in the activeness of speaking in English. In general, the activeness of speech is clearly seen in meetings 2 and 3 where students acting as chairman of committee actively express their opinions in English. So that in cycle 2, the speaking skills of the chairman of the committee are considered to be quite good. Students show an increase in good interaction with their interlocutors. Interaction is not only shown by lecturers to students but also by students to lecturers. This can be concluded based on student responses to lecturers' oral communication by carrying out all the commands correctly. In addition, lecturers can also respond to students' oral communication correctly and continuously, meaning that in every oral communication between students and lecturers, both parties can continuously provide feedback on each response that is said.

The value of English speaking skills on the fluency aspect that starts from the ability of public speaking on the speech of the chairman of committee in cycle II can be seen in table 4.2 below: 
Table 2. Value of Fuency Skills in Speaking English in Cycle II

\begin{tabular}{|c|c|c|c|}
\hline \multirow{2}{*}{ No. } & Score & \multirow{2}{*}{ No. } & Score \\
\cline { 2 - 4 } & Fluency & & Fluency \\
\hline 1. & 2 & 15. & 2 \\
\hline 2. & 3 & 16. & 4 \\
\hline 3. & 2 & 17. & 4 \\
\hline 4. & 3 & 18. & 3 \\
\hline 5. & 2 & 19. & 3 \\
\hline 6. & 3 & 20. & 3 \\
\hline 7. & 2 & 21. & 3 \\
\hline 8. & 3 & 22. & 3 \\
\hline 9. & 4 & 23. & 3 \\
\hline 10. & 2 & 24. & 3 \\
\hline 11. & 2 & 25. & 3 \\
\hline 12. & 3 & 26. & 4 \\
\hline 13. & 3 & 27. & 3 \\
\hline 14. & 3 & & \\
\hline Total & \multicolumn{3}{|l}{78} \\
\hline Average & \multicolumn{2}{|l}{2,89} \\
\hline & \multicolumn{2}{|l}{} \\
\hline
\end{tabular}

Based on the results of the achievement of speaking skills in the second cycle visualized through the table above is the total fluency value of speaking English students a total score of 78 and a fluency average value of $2 \mathrm{~A}$ in semester $4 \mathrm{~A}$ of 2.89. 2 .

\section{Cycle III}

\section{Planning}

The formulation of the plan in cycle III is the strengthening of the implementation of the role playing method to improve fluency skills to speak English, namely sharpening reflection, namely field notes found in the learning process that are still lacking which include active speaking, lecturer and student interaction, interaction between students, student attention in the learning process speak English, and fluency skills speak English students. b) Implementation of Actions and Observations In an effort to solve the problems faced by students in the cycle of the implementation of the cycle III action carried out twice. Meeting 1 is giving material material about public speaking on speech of chairman of committee. Meetings 2 and 3 are role-playing activities in which the implementation process is observed and assessed.

\section{(a) Meeting 1}

The 1st meeting in the third cycle was conducted by discussing about public speaking on speech of the chairman of committee. Discussion is stated as necessary because based on observations in cycle II, students still make mistakes in pronouncing a word and even a sentence even though the error has decreased. In the pre-activity, the activity is an explanation of public speaking on the speech of the 
chairman of the committee, and continues on the Whilst activity, namely the practice of role-playing learning strategies. To facilitate understanding, examples of vocabulary words related to public speaking on speech of chairman of committee are prepared. In post-activity, the activity ends with a conclusion about public speaking on speech of the chairman of committee in the next role-playing practice.

\section{(b) Meetings 2 and 3}

The second and third meetings of the third cycle took the form of role-playing performances for students in sessions 2 and 3. In the pre-activity activities, the preparation of the practice of role-playing by students. In whilst-activity, role-playing activities carried out by students vary which focus of observation is carried out by the researcher, namely observations on the fluency aspect and the use of expressions of understanding or understanding.

\section{Reflection}

Cycle III shows an increase in the activeness of speaking in English. In general, activeness of speech is clearly seen in meetings 2 and 3 where students who act as public speaking on speech of the chairman of committee actively express their opinions in English. So that in cycle 2, fluency skills speak English by the actor of public speaking on speech of chairman of committee are considered quite good. Students show an increase in good interaction with their interlocutors. Interaction is not only shown by lecturers to students but also by students to lecturers. This can be concluded based on student responses to lecturers' oral communication by carrying out all the commands correctly. In addition, lecturers can also respond to students' oral communication correctly and continuously, meaning that in every oral communication between students and lecturers, both parties can continuously provide feedback on each response that is said.The value of fluency skills speaks English on the fluency aspect which starts from the ability to open, convey, and close the lesson using English in the third cycle can be seen in table 4.3 below:

Table 3. Value of Fluency Skills in English Speaking in Cycle III

\begin{tabular}{|c|c|c|c|}
\hline \multirow{2}{*}{ No. } & Score & \multirow{2}{*}{ No. } & Score \\
\cline { 2 - 4 } & Fluency & & Fluency \\
\hline 1. & 2 & 15. & 3 \\
\hline 2. & 3 & 16. & 4 \\
\hline 3. & 2 & 17. & 4 \\
\hline 4. & 3 & 18. & 3 \\
\hline 5. & 3 & 19. & 3 \\
\hline 6. & 3 & 20. & 3 \\
\hline 7. & 3 & 21. & 4 \\
\hline 8. & 3 & 22. & 3 \\
\hline 9. & 4 & 23. & 4 \\
\hline 10. & 3 & 24. & 3 \\
\hline 11. & 3 & 25. & 3 \\
\hline 12. & 3 & 26. & 4 \\
\hline 13. & 3 & 27. & 4 \\
\hline 14. & 3 & & \\
\hline Total & \multicolumn{3}{|c}{86} \\
\hline Average & \multicolumn{3}{|l}{3.19} \\
\hline
\end{tabular}


Based on the results of the achievement of speaking skills in the third cycle visualized through the table above is the total fluency value of speaking English students a total value of 86 and a fluency average value of $2 \mathrm{~A}$ in semester $4 \mathrm{~A}$ of 3.19 .

\section{Discussion}

The increase in the average value of English speaking skills from the first to the third cycle in this study supports the results of a study conducted by Shen and Suwanteph (2011) in Thailand, which used role-playing to improve student speaking skills and Kirkgoz (2001) in Turkey, who uses role-playing in learning to speak English. The results of Shen and Suwanteph's research showed that role playing has a positive influence on improving student skills in speaking, especially in terms of quality and language production. While the results of Kirkgoz's research show the use of role playing in learning to speak English is able to provide a positive influence on increasing the average value of students and able to foster a critical attitude of students in discussions, assess their own skills and classmates. The post-test results are supported by data obtained from the results of questionnaires filled out by students. Based on the percentage of the results of the questionnaire, it can be concluded that almost all students say they like the role playing technique in the learning process.

The technique helps them to be active in speaking English, lecturer and student interaction, interaction between students, and the attention of students in learning to speak English. In role playing, more than half of the students said they were able to give a good response to the questions given, sure what they said could be understood by their colleagues and they felt they were able to have good conversations, and did not experience difficulties regarding the topics discussed. In addition, students feel that they get a lot of input regarding their strengths and weaknesses and can learn from their friends' strengths and mistakes in speaking. The results of these questionnaires are in accordance with the principles proposed by Brown (2001), namely role playing techniques are said to prioritize the needs of students to talk from those that focus on accuracy to those that focus on messages, interactions, meaning and fluency. In addition, this technique can also motivate students from within themselves, encourage the use of authentic language in a meaningful context, capable of facilitating appropriate feedback and correction, emphasizing the natural connection between speaking and listening, giving students the opportunity to start oral communication and encourage the growth of speaking strategies. In addition, according to what Ur (1996) explained, role playing is an appropriate learning technique to increase selfconfidence and cooperation between students if implemented effectively. By participating in certain roles, students will slowly see that they can, so that in turn they will feel confident to talk. In addition, Ur also revealed that role playing also provides an opportunity for students to practice real life spoken language in the classroom. The same idea was also expressed by Harmer (2002) who stated that role playing is an activity that is fun and motivating, increases self-confidence, and provides opportunities for students to use a wider variety of languages by incorporating the "outside world" into the classroom. Based on the reflection and discussion above, the results of this study are in accordance with the study of theory and empirical evidence relating to the use of role playing to improve English speaking skills. However, to further improve fluency skills speak English 2A semester 4A graders of the English Language Study Program at the State Polytechnic of Madiun, there are several things that must be improved in the future, namely students must exercise more skills at home to improve fluency in speaking English, avoid repeating words and think faster about the words to be spoken so that there is no long pause in speaking, lots of reading to increase knowledge about vocabulary, learn more about grammar, and practice speaking skills in front of friends to reduce the feeling of nervousness in speaking. 


\section{Conclusion}

Based on the analysis of the learning process by using role playing learning strategies to improve fluency skills speaking English in the first cycle to cycle III fluency skills speaking their English increased significantly, from 2.44 to 3.19. In addition, students were very interested and pleased with the implementation of role playing learning strategies to improve students' English skills as indicated by the results of student questionnaires. From the average value of cycle III can be stopped in cycle III because it meets the criteria of success.

The researcher concluded that the implementation of role-playing techniques was proven to be able to improve fluency skills in speaking English in 2A semester 4A grade students of the English Polytechnic Madiun Study Program. There are students starting from the pre-test, post-test I cycle I, posttest III, and post-test cycle III. In the post-test III, the average score of students has reached the standard of completeness, so that the study can end up in the third cycle only. The increase in the average value of students occurs gradually and is accompanied by the impression of students on role playing learning strategies. More and more students feel more like the techniques used and feel helped and motivated in fluency speaking English. The things that still need to be improved by students are to train mentally so that they don't get nervous when speaking in front of the class and improve their ability in terms of pronunciation and vocabulary diversity by reading a lot, both reading aloud and reading comprehension. Besides that, the thing that must get serious attention is fluency because students are still not able to speak with good and correct English grammar.

This research is an innovative effort in learning fluency skills in English speaking which is applied in the English Study Program, State Polytechnic of Madiun. For this reason, the results of the research obtained are expected to contribute optimally to students. Students can improve their skills in fluency in English speaking by using a fun learning strategy that is playing roles according to the topics studied and pouring their creativity together in the classroom. Students can learn from their own mistakes and those of their friends, and make it a reference to appear better in the future. In speaking, students must be able to overcome feeling nervous, pay attention and respect the opinions of others, and improve their abilities in terms of aspects of speaking. For lecturers, lecturers can use role playing learning strategies because this learning strategy is proven to be able to improve fluency skills in speaking English in grade 2A English Study Program at State Polytechnic of Madiun. The role playing learning strategy can be used as an alternative in designing English teaching and learning activities. Things that need to be prepared to facilitate the course of activities in the classroom are learning plans, materials, laptops, LCDs, and whiteboards. In addition, through informal talks, seminars, and papers, the results of this study can be known by other lecturers, and can be used as performance improvement materials and are useful to increase the insight of educators, adding to the repertoire of science and education and teaching.

\section{References}

Adnyani, L. D. S \& Dambayana, P. E. 2014. Penerapan Teknik Role Play Dengan Bantuan Video Pada Mata Kuliah Speaking 2 Untuk Meningkatkan Keterampilan Berbicara Mahasiswa Jurusan Pendidikan Bahasa Inggris Undiksha Tahun Ajaran 2011/2012. Jurnal Pendidikan Indonesia, 3 (1): $313-325$.

Amato, P. \& Richards. (2003) Making it Happen: From Interactive to Participatory Language Teaching. New York: Pearson Education, Inc. 
Arevat, S. \& Nation P. 1991. Fluency Improvement in a Second Language. Victoria: University of Wellington.

Argaruri, Y. 2014. Penerapan Model Pembelajaran Role Playing Untuk Meningkatkan Keterampilan Berbicara Siswa Kelas V Sd Negeri 1 Japan Pada Mata Pelajaran Bahasa Indonesia. Disertasi tidak diterbitkan. Kudus: Universitas Muria Kudus. http://www.distrodoc.com/263778-penerapanmodel-pembelajaran-role-playing-untuk-meningkatkan-3, accessed on April 27, 2015

As'adi, M. 2011. Efektivitas Penggunaan Role Playing dalam Peningkatan Keterampilan Berbicara. Thesis tidak diterbitkan. Malang: UIN Maulana Malik Ibrahim. http://lib.uin-malang.ac.id/?mod=th_detail\&id=09720061, accessed on April 27, 2015.

Brand, C., \& Götz, S. (2011). Fluency versus accuracy in advanced spoken learner language: A multimethod approach. International Journal of Corpus Linguistics, 16,255-275. doi:10.1075/ijcl.16.2.05bra.

Brand, C., \& Götz, S. (2011). Fluency versus accuracy in advanced spoken learner language: A multimethod approach. International Journal of Corpus Linguistics, 16, 255-275. doi:10.1075/ijcl.16.2.05bra.

Brown, H. Douglas. (2001). Teaching by Principles: An Interactive Approach to Language Pedagogy $(2 n d e d)$. New York: Pearson Education Company.

Crowther, D., Trofimovich, P., Isaacs, T., \& Saito, K. (2015). Does a speaking task affect second language comprehensi-bility? Modern Language Journal, 99, 80-95. doi:10.1111/modl.12185.

Devito, Joseph A. 1990. The Elements of public Speaking. New York: Harper Collins Publisher.

Fletcher, L. 1990. How to Design and Deliver A Speech: Fourth Edition. New York: Harper Collins Publisher.

Harmer, J. \& Hadfield (2002). The Practice of English Language Teaching (4th ed). New York: Pearson Longman.

Heliyenti, Eva. 2014. Penerapan Model Pembelajaran Role Play Untuk Meningkatkan Kemampuanmenyimak Dan Berbicara Bahasa InggrisSiswa Kelas Viii Mtsn 2 Kota Bengkulu. Thesis tidak diterbitkan. Bengkulu: Universitas Bengkulu. http://repository.unib.ac.id/9417/ accessed on April 27, 2015.

Herman J. Waluyo. 2002. Apresiasi Puisi. Jakarta: PT. Gramedia Pustaka Utama.

Housen, A., \& Kuiken, F. (2009). Complexity, accuracy, and flu-ency in second language acquisition. Applied Linguistics, 30, 461-473. doi:10.1093/applin/amp048.

Jill Hadfield (1986). Classroom Dynamic. Oxford University Press.

Joyce, B. R., \& Weil, M. (2000). Role Playing; Studying Social Behavior and Values. In Models of Teaching. Allyn and Bacon.

Khudriyah. 2010. The Implementation of Role Play to Improve the EFL Speaking Ability of the Fourth Semester Students of STIT Al Urwatul Wutsqo Jombang. Malang: PPs UM. 
Klippel, F. 1984. Keep Talking, Communicative Fluency Activities for Language Teaching. Cambridge University Press.

Kirkgoz, Y. 2011. A Blended Learning Study on Implementing Video Recorded Speaking Tasks In TaskBased Classroom Instruction. TOJET: The Turkish Online Journal of Educational Technology. October 2011, volume 10 Issue 4. Downloaded February 15, 2012 at http://www.tojet.net/articles/v10i4/1041.pdf

Lee, W. R. (1986). Language Teaching Games and Contests (2nd ed). New York: Oxford University Press.

Martinis Yamin. 2008. Desain Pembelajaran Berbasis Tingkat Satuan Pendidikan. Jakarta: Gaung Persada Pers.

Mc. Niff, J. 1988. Action Research: Priciples and Practice. New York: Chapman and Hall Inc.

Mudofir, I. 2015. Metode Role Playing Untuk Meningkatkan Kemampuan Berbicara Bahasa Inggris Mahasiswa Politeknik Negeri Malang. DIPA Politeknik Negeri Malang.

Nakatani, Y. (2010). Identifying strategies that facilitate EFL Learners' oral communication: A classroom study using multi-ple data collection procedures. The Modern Language Journal, 94, 116-137.

Nunan, David. (1989). Designing Task for the Communicative Classroom. Cambridge: Cambridge University Press.

Oemar Hamalik. 2005. Proses Belajar Mengajar. Jakarta: Bumi Aksara.

Poorman,P.B.(2002. Biography and role-playing:fostering empathy in abnormal psychology. Teaching of Psychology.

Purwanto. 2013. Penggunaan metode role playing untuk meningkatkan kemampuan berbicara siswa kelas VIII A SMP Negeri 3 Paron. JURNAL INDUKSI - Jurnal Dinas Pendidikan Kabupaten Ngawi. http://jurnal-induksi.com/edisi-1/penggunaan-metode-role-playing-untuk-meningkatkankemampuan-berbicara-siswa-kelas-viii-a-smp-negeri-3-paron/ accessed on April 27, 2015.

Rianti, A. P. 2013. Peningkatan Kemampuan Berbicara Bahasa InggrisMelalui Teknik Role Play Pada Siswa Kelas X Akomodasi Perhotelan Di Smk Pgri 4 Denpasar. Thesis Tidak Diterbitkan. Denpasar: Universitas Udayana. Http://Www.Pps.Unud.Ac.Id/Thesis/Detail-630-PeningkatanKemampuan-Berbicara-Bahasa-Inggris-Melalui-Teknik-Role-Play-Pada-Siswa-Kelas-XAkomodasi-Perhotelan-Di-Smk-Pgri-4-Denpasar.Html accessed on April 27, 2015.

Richards, J. C. \& Renandya, W. A. (2002) Methodology in Language Teaching: An Anthology of Current Practices. New York: Cambridge University Press.

Schultz. 1976. Stephen Krashen's Theory of Second Language Acquisition. (Online). (www.sk.com.br/skkrash.html), accessed December 1,2006.

Shen, L.,dan Suwanteph, J. 2011. E-learning Constructive Role Plays for EFL Learners in China"s Tertiary Education. Asian EFL Journal. Professional Teaching Articles. Vol. 49 January 2011. Downloaded February 15, 2012 at http://www.asian-efl-journal.com/PTA/January 2011.pdf. 
Susilo, A. 2011. The use of role play to anhance students speaking skill (a classroom action research at second grade of SMP Darul Ma'arif Fatmawati). Skripsi tidak diterbitkan. Jakarta: UIN Syarif Hidayatullah. http://repository.uinjkt.ac.id/dspace/handle/123456789/4115 accessed on 27 April 2015 .

Sutino. 2011. Penerapan Teknik Role Play Dengan Bantuan Video Pada Mata Kuliah Speaking 2 Untuk Meningkatkan Keterampilan Berbicara Mahasiswa Jurusan Pendidikan Bahasa InggrisUndiksha Tahun Ajaran 2011/2012. Skripsi tidak diterbitkan. Surakarta: Universitas Sebelas Maret.

Tarigan. (1981). Batasan dan Tentang Bahasa dalam Berbicara Sebagai suatu siswa Kelas 2 SMP Negeri 6 Serang. Jakarta: mhtml : file//F:Imajalah \%20 skripsi \%20 PENGARUH \%20 PENGUASAAN $\% 20$ TEORI \%20 BE.

Triyanto, A. 2013. Pengaruh Metode Bermain Peran (Role Playing)Terhadap Hasil Belajar IPA Pada Konsep Penggolongan Hewan (Kuasi Eksperimen Pada Kelas III Madrasah Ibtidaiyah NurAttaqwa Kelapa Gading Jakarta). Skripsi tidak diterbitkan. Jakarta: Universitas Islam Negeri Syarif Hidayatullah.

Ur, P. 1996. A Course in language teaching: Practice and Theory. Cambridge: Cambridge University Press.

Widiastuti, W. 2012. Keefektifan Penerapan Teknik Role Playing Dalam Pembelajaran Keterampilan Berbicara Bahasa Jawa Di Kelas IV SD Negeri Tegal Panggung. Skripsi tidak diterbitkan. Yogayakarta: Universitas Negeri Yogyakarta.

\section{Copyrights}

Copyright for this article is retained by the author(s), with first publication rights granted to the journal. This is an open-access article distributed under the terms and conditions of the Creative Commons Attribution license (http://creativecommons.org/licenses/by/4.0/). 